\title{
PENDAMPINGAN BELAJAR DARI RUMAH (BDR) WARGA DUKUH GEMPOL SEBAGAI UPAYA REVITALISASI PENDIDIKAN PADA MASA PANDEMI
}

\author{
LEARNING ASSISTANCE FROM THE HOME (BDR) \\ OF DUKUH GEMPOL RESIDENTS AS EDUCATION \\ REVITALIZATION EFFORTSIN THE PANDEMIC TIME
}

\author{
Anisa Alfiolia ${ }^{1)}$, Helen Mandasari ${ }^{2)}$, Larasati Siti Maryam ${ }^{3)}$, Wibowo Heru \\ Prasetiyo $^{4)}$, Laili Etika Rahmawati ${ }^{\text {) }}$ \\ ${ }^{12345}$ Fakultas Keguruan dan Ilmu Pendidikan, Universitas Muhammadiyah Surakarta \\ ${ }^{4}$ Email:whp823@ums.ac.id
}

\begin{abstract}
Abstrak: Pendidikan merupakan hal terpenting untuk mencapai tujuan nasional bangsa Indonesia yaitu mencerdaskan kehidupan bangsa. Pada Masa pandemi mengharuskan pembelajaran dilaksanakan secara daring atau Belajar dari Rumah (BDR). Terdapat beberapa permasalahan BDR sehingga perlu dilakukan pendampingan untuk mengatasinya. Pendampingan BDR dilakukan dengan beberapa tahap yaitu: (1) Membimbing dan menjelaskan kepada siswa mengerjakan tugas yang diberikan oleh gurunya, (2) Menyapaikan materi kepada siswa secara ceramah, (3) Melaksanakan tanya jawab materi yang telah dipelajari. Pendampingan BDR memberikan hasil yang baik yaitu siswa memiliki minta dan antusias yang tinggi dalam pelaksanakan pendampingan belajar dan orang tua siswa juga merasa senang dan terbantu dengan adanya program pendampingan belajar karena dapat meringankan beban orangtau dalam mendam-pingi anaknya saat pembelajaran daring atau BDR.
\end{abstract}

Kata Kunci: Belajar dari rumah, Pendidikan masa pandemi, Revitalisasi pendidikan

Abstract: Education is the most important thing to achieve the national goal of the Indonesian nation, which is to educate the nation's life. During the pandemic period, learning is required to be carried out online or Learning from Home (BDR). There are several BDR problems so that assistance is needed to solve them. BDR assistance is carried out in several stages, namely: (1) Guiding and explaining to students doing the assignments given by the teacher, (2) Presenting material to students in lectures, (3) Carrying out question and answer material that has been studied. BDR mentoring gives good results, namely students have high demand and enthusiasm in implementing learning assistance and parents also feel happy and helped by the learning assistance program because it can ease the burden on parents in accompanying their children during online learning or BDR.

Keywords: Learning from home, Education during the pandemic, Revitalizing education 
INTEGRITAS : Jurnal Pengabdian

Vol 5 No 2 Desember 2021

ISSN 2580 - 7978 (cetak) ISSN 2615 - 0794 (online)

\section{PENDAHULUAN}

Pandemi Coronavirus Disease (COVID-19) telah menyebar ke berbagai negara termasuk Indonesia. Hal tersebut mengharus-kan berbagai sektor termasuk pendidikan segera mengambil berbagai kebijakan agar memutus mata rantai penyebaran virus. Menteri pendidikan dan kebudayaan Republik Indonesia telah megeluarkan Surat Edaran No 4 Tahun 2020 tentang pelaksanaan kebijakan pendidikan dalam masa darurat penyebaran corona virus disease (COVID-19) di mana penyelenggaraan pembelajaran dilakukan dengan Belajar dari Rumah melalui pembelajaran daring/jarak jauh (Rebublik Indonesia 2020).

Pelaksanaan Belajar dari Rumah (BDR) atau pembelajaran daring di Indonesia sudah dilaksanakan sejak Maret 2021. Pelaksanaan tersebut dapat berjalan dengan baik di beberapa daerah dan mendapatkan kendala di beberapa daerah. Menurut (Arifa 2020) "Proses belajar dari rumah yang dilaksanakan saat ini belum dapat disebut sebagai kondisi belajar yang ideal, melainkan kondisi darurat yang harus dilaksanakan. Masih terdapat berbagai kendala sehingga semua pembela-jaran dapat optimal”.

Terdapat beberapa kendala yang dialami oleh murid, guru dan orang tua dalam kegiatan belajar mengajar online yaitu penguasaan teknologi masih kurang, penambahan biaya kuota internet, adanya pekerjan tambahan bagi orang tua dalam mendampingi anak belajar, komunikasi dan sosialisasi antar siswa, guru dan orang tua menjadi berkurang dan Jam kerja yang menjadi tidak terbatas bagi guru karena harus berkomunikasi dan berkoordinasi dengan orang tua, guru lain, dan kepala sekolah (Purwanto 2020). Hal ini juga terjadi di Dukuh Gempol Rt 18 Desa Mojodoyong dimana para orang tua kesulitan untuk mendampingi anaknya dalam pembelajaran daring. Beberapa orang tua sibuk dengan pekerjaannya dimana mayoritas warganya berprofesi sebagai petani.

Tanpa adanya pendampingan maka siswa hanya akan tumbuh saja namun tidak berkembang sebagaimana tujuan pendidikan yang semestinya sebagaimana terdapat dalam UU No 20 Tahun 2003 tantang Sistem Pendidikan Nasiona bahwa Pendidikan adalah usaha sadar dan terencana untuk mewujudkan suasana belajar dan proses pembelajaran agar peserta didik secara aktif mengembangkan potensi 
dirinya untuk memiliki kekuatan spiritual keagamaan, pengendalian diri, kepribadian, kecerdasan, akhlak mulia, serta keterampilan yang diperlukan dirinya, masyarakat, bangsa dan negara (Republik Indonesia 2003).

Banyaknya permasalahan yang ada maka diperlukan metode agar pendidikan di Indonesia tetap bisa berjalan dengan baik. Salah satu upaya yang dapat dilakukan adalah dengan melakukan revitalisasi pendidikan. Menurut (Borualogo 2005), revitalisasi pendi-dikan harus dilakukan guna memaksimalkan potensi yang selama ini sesungguhnya telah dimiliki oleh bangsa Indonesia. Revitalisasi pendidikan di masa pandemi ini membutuhkan peran pendampingan bagi siswa, salah satu pendamping yang memegang peran besar dalam pelaksanaan pembelajaran daring adalah orang tua siswa. Orang tua memiliki peran sebagai pembelajar anak, pemenuh kebutuhan anak, pemahaman spiritual, pengawasan, motivasi, dan penyedia fasilitas anak. Pendampingan belajar anak terlihat dari cara orang tua membantu kesulitan tugas anak, menjelaskan materi yang tidak dimengerti anak, dan merespon dengan baik semua pembelajaran daring dari sekolah (Yulianingsih and Nugroho 2021).

Berdasarkan hal tersebut maka dirasa perlu untuk melaksanakan Kegiatan Kuliah Kerja Nyata Pendidikan (KKN-Dik) di Dukuh Gempol. KKN-Dik merupakan bentuk kegiatan yang memberikan pengalaman belajar kepada mahasiswa untuk hidup di tengah-tengah masyarakat luar kampus. Kegiatan KKN-Dik bertujuan agar mahasiswa belajar menerapkan ilmu dan pengalaman yang diperoleh selama duduk di bangku kuliah dalam mengatasi berbagai permasalahan yang terjadi dalam kehidupan nyata di masyarakat (Prayitno dkk., 2018).

KKN-Dik dilaksanakan berfokus pada Pendampingan BDR Warga Dukuh Gempol sebagai Upaya Revitalisasi Pendidikan pada Masa Pandemi. Pendampingan ini bertujuan untuk mengembangkan minat belajar anak melalui kegiatan bimbingan belajar, meringan-kan beban orang tua dalam pendampingan pembelajaran daring, dan merevitalisasi pendidikan yang sudah ada di masa pandemi. 


\section{METODE}

Metode yang digunakan dalam peneli-tian ini adalah sosialisasi dan pendampingan belajar. Sosialisasi bimbingan belajar daring dilaksanakan satu kali pada awal kegiatan KKN-Dik dengan sasaran orang tua yang memiliki anak usia sekolah dasar dan menengah. Pendampingan belajar TPA dilaksanakan setiap satu minggu tiga kali pada hari Senin, Selasa, dan Rabu dengan sasaran anak yang masih menempuh pendidikan Sekolah Dasar (SD) dan Sekolah Menengah Pertama (SMP). Pendampingan belajar dilaksana-kan secara rutin sebanyak tiga kali satu minggu pada hari Senin, Rabu, dan Kamis dengan sasaran anak yang masih menempuh pendidikan Sekolah Dasar (SD).

Pendampingan belajar dilaksanakan dalam tiga tahap yaitu: (1) Membimbing dan menjelaskan kepada siswa mengerjakan tugas yang diberikan oleh gurunya, (2) Menyapaikan materi kepada siswa secara ceramah, (3) Melaksanakan tanya jawab materi yang telah dipelajari. Teknik pengumpulan data dilaku-kan degan obeservasi dan wawancara. Pengabdian dilakukan pada waktu kegiatan KKN-Dik yang berlangsung dari bulan Februari sampai bulan Maret 2021 dan bertempat di Dukuh Gempol Rt/Rw 18/05, Desa Mojodoyong, Kecamatan Kedawung, Kabupaten Sragen.

\section{HASIL DAN PEMBAHASAN}

Program kerja dari kegiatan KKN-Dik yang dilakukan mengarah pada revitalisasi pendidikan di masa pandemi dengan melakukan pendampingan BDR. Program kerja yang dilaksanakan bertujuan untuk memberikan revitalisai terhadap pendidikan yang sebelumnya telah dilakukan di tempat kegiatan KKN-Dik namun belum terlaksana secara optimal. Selain itu pengabdian ini bertujuan untuk menyelesaikan permasalahan yang ada selama BDR baik yang dialami oleh siswa maupun orangtua siswa. Program kerja yang dilakukan diantaranya:

\section{Sosialisasi Bimbingan Belajar Daring Kepada Orang Tua}

Teknis pelaksanaan BDR sudah dipahami oleh, siswa namun tanpa adanya pendampingan oleh orangtua maka siswa tidak akan mampu melaksanakan BDR secara maksimal sehingga tugas belajar dan perkembangan siswa tidak dapat dicapai secara aksimal. Tidak hanya itu, siswa juga sering mengalami kesulitan 
INTEGRITAS : Jurnal Pengabdian

Vol 5 No 2 Desember 2021

ISSN 2580 - 7978 (cetak) ISSN 2615 - 0794 (online)

dalam mengatur waktu belajarnya dan lebih condong menghabiskan waktunya untuk bermain hingga terkadang lupa dengan tanggung jawabnya. Hal ini membuktikan bahwa peran orangtua sangat besar dalam pelaksanaan BDR. Menurut (Islami 2021), "Keberhasilan anak dalam pembelajaran tidak terlepas dari peran orang tua yang memotivasi atau yang menjadi penggerak dan pendorong agar anaknya dapat maju dan perkembang dalam pendidikan". Berdasarkan hal tersebut maka dirasa perlu untuk memberikan sosialisasi bimbingan belajar daring kedapa orang tua agar mereka faham dan mampu mendambingi anaknya dalam melaksanakan BDR secara maksimal.

Kegiatan sosialisasi ini dilaksanakan dengan mengarahkan orang tua agar memberikan pendampingan kepada anaknya dalam melaksanakan BDR. Tujuan diadakannya sosialisasi ini adalah agar orang tua lebih memperhatikan serta lebih peduli lagi kepada anaknya dalam melaksanakan BDR sehingga anak-anak merasa semangat belajarnya dan merasa memiliki tanggung jawab dalam pelaksanaan pembelajaran daring. Tujuan lain adalah agar anak-anak tidak hanya asyik bermain sepanjang hari namun juga selalu ingat kewajibannya untuk belajar sehingga disamping bermain juga belajar dengan pendampingan orang tua.

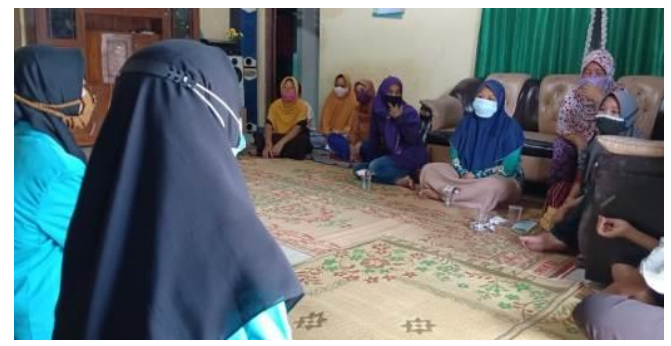

Gambar 1. Sosialisasi Bimbingan Belajar Daring Kepada Orang Tua

Program kerja ini dilaksanakan pada hari Minggu, 07 Februari 2021 bertempat di rumah ketua RT 18 Dukuh Gempol. Kegiatan ini diikuti oleh orang tua yang memiliki anak usia sekolah dasar dan menengah. Kegiatan ini berjalan dengan lancar tanpa ada kendala yang berarti. Orang tua yang mengikuti sosialisasi sangat antusias dan memahami materi yang disampaikan. Kegiatan dilaksanakan dengan mematuhi protokol kesehatan. Peserta sebelum mengikuti kegiatan mencuci tangan terlebih dahulu, memakai masker, dan menjaga jarak. 
Kegiatan sosialisasi pendampingan belajar daring kepada orangtua sangat diperlukaan terlebih pada masa pandemi ini. Orangtua merupakan garda terdepan pelaksanaan pembelajaran daring, hal ini karena orangtua memiliki peran ganda yaitu sebagai orang tua dan sebagai guru bagi anaknya. Hal serupa juga diutarakan oleh (Alpian dkk., 2020), bahwa orang tua memiliki peran yang besar dalam mendampingi kesuksessan pendidikan anak selama belajar di rumah karena pada masa pandemi Covid-19 ini anak lebih cenderung memiliki banyak waktu belajar di rumah.

Kegiatan sosialisasi bimbingan belajar daring kepada orang tua yang dilaksanakan di Dukuh Gempol, Desa Mojodoyong, Kecamatan Kedawung, Kabupaten Sragen terbukti dapat membuka pandangan orangtua untuk selalu mendampingi anaknya dalam pelaksanaan pembelajaran daring. Hal ini juga diutarakan oleh (Nurpratiwiningsih dkk., 2021), bahwa sosialisasi pendampingan orangtua dalam pembelajaran daring dapat membuka persepsi dan pemahaman bagi orang tua dalam mendidik dan mengajar anaknya. Hal serupa juga disampaikan oleh (Mawar dkk., 2020), bahwa kegiatan sosialisasi peranan orangtua dalam pembelajaran daring dimasa pandemi Covid-19 membuat orang tua menyadari betapa pentingnya peran orang tua sehingga mereka akan senantiasa memberikan semangat kepada anaknya dalam proses pembelajaran.

\section{Program Pendampingan Belajar Siswa Sekolah Dasar (SD)}

Pelaksanaan BDR oleh siswa akan krang maksimal jika tidak diimbangi oeh orang tua atau orang yang mampu untuk mendampingi. Di Dukuh Gempol sendiri tidak semua orang tua bisa mendampingi anaknya dalam melaksanakan BDR, hal ini karena sebagian orang tua sibuk dengan pekerjaannya dan ada pula yang tidak mengerti dengan materinya. Berdasarkan hal tersebut maka diaggap perlu untuk melaksanakan program pendampingan belajar khususnya bagi siswa kelas satu sampai enam tingkat sekolah dasar di Dukuh Gempol.

Tujuan dari kegiatan ini adalah agar siswa lebih semangat lagi dan terbantu dalam melaksanakan pembelajaran daring yang diadakan oleh sekolahannya. Pendampingan belajar juga bertujuan agar siswa terbantu dalam menyelesaikan 
tugas belajarnya secara optimal dalam pelaksanaan BDR sehingga siswa tidak hanya tumbuh saja namun juga berkembang sesuai dengan tugas kembangnya.

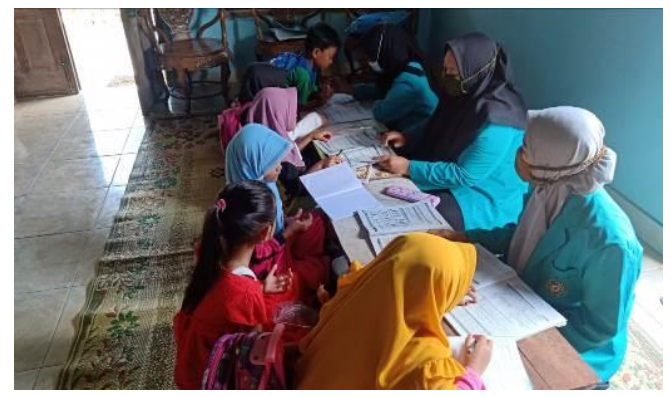

Gambar 2. Pendampingan Belajar Siswa Kelas 1 dan 2

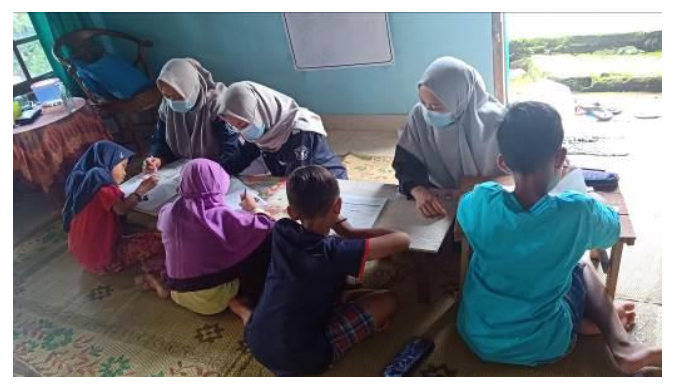

Gambar 3. Pendampingan Belajar Siswa Kelas 3 dan 4

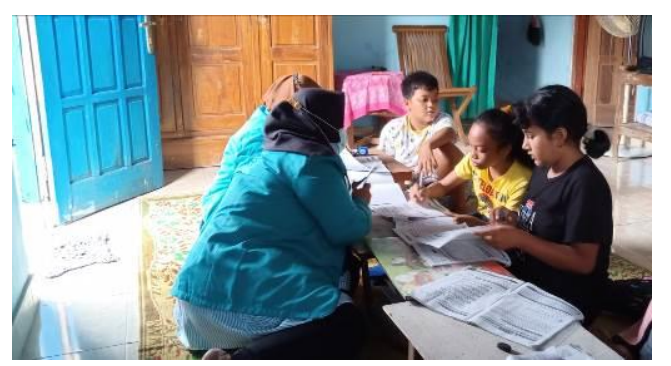

Gambar 4 Pendampingan Belajar Siswa Kelas 5 dan 6

Program pendampingan belajar ini dilaksanakan secara rutin setiap satu minggu tiga kali pada pukul 12.00-14.00 dengan jadwal yang telah ditentukan sesuai tingkatannya mulai dari periode 01 Februari sampai 06 Maret 20201. Pendampingan belajar siswa tingkat 1 dan 2 SD dilaksanakan setiap hari Kamis, siswa tingkat 3 dan 4 dilaksanakan setiap hari Senin, dan siswa tingkat 5 dan 6 dilaksanakan setiap hari Rabu. Pelaksanaan pendampigan belajar dilakukan dengan memberikan pendampingan kepada siswa untuk menyelesaikan tugas belajarnya selama BDR. Pendampingan belajar dilaksanakan dalam tiga tahap yaitu: (1) Membimbing dan menjelaskan kepada siswa mengerjakan tugas yang 
INTEGRITAS : Jurnal Pengabdian

Vol 5 No 2 Desember 2021

ISSN 2580 - 7978 (cetak) ISSN 2615 - 0794 (online)

diberikan oleh gurunya, (2) Menyapaikan materi kepada siswa secara ceramah, (3) Melaksanakan tanya jawab materi yang telah dipelajari. Selain itu kegiatan ini juga mengajarkan kepada siswa untuk meningkatkan rasa nasionalisme siswa dengan mengajarkan lagu-lagu nasional dan memahamkan mengenai makna Pancasila sebagai dasar negara.

Program pendampingan belajar terlaksana dengan baik tanpa ada kendala yang berarti. Program ini diikuti oleh lima siswa kelas satu dan dua, empat siswa kelas tiga dan empat, dan lima siswa kelas lima dan enam. Pelaksanaan kegiatan ini selalu diikuti dengan semangat dan antusias tinggi oleh anak-anak. Mereka merasa senang karena dalam pelaksanaan BDR ada yang membimbing. Anakanak dapat memahami materi pembelajaran dengan baik dan lebih hafal serta faham lagi mengenai lagu-lagu nasional dan dasar negara Pancasila.

Program pendampingan belajar siswa sekolah dasar yang dilaksanakan di Dukuh Gempol, Desa Mojodoyong, Kecamatan Kedawung, Kabupaten Sragen ini memang benar-benar diperlukan karena dapat membantu meringankan beban orang tua siswa yang merasa kesulitan dalam membimbing anknya. Selain itu pendampingan belajar mampu meningkatkan minat belajar siswa, motivasi siswa menjadi tinggi serta mereka terbantu dengan adanya bimbingan belajar ini, karena tidak semua materi dapat siswa pahami sendiri sehingga membutuhkan bantuan orang lain untuk memahaminya. Pendapat serupa juga diuarakan oleh (Handayani dkk., 2020), bahwa orang tua terbantu dengan adanya kegiatan pendampingan belajar karena kegiatan ini membuat siswa menjadi lebih paham dengan materi yang diajarkan oleh guru. Pendapat lain disampaikan oleh (Sudarti dkk 2021), bahwa dengan adanya pendampingan belajar siswa merasa terbantu sehingga motivasi belajar dan hasil belajar siswa mengalami peningkatan.

\section{Pendampingan Belajar TPA}

Masa pandemi Covid-19 mengharuskan pembelajaran dilakukan secara daring sehingga siswa kurang mendapatkan pendidikan karakter terutama terkait agama. berdasarkan hal tersebut maka dirasa perlu untuk tetap melaksanakan pendampingan belajar di TPA agar walaupun masa pandemi karakter religus siswa tetap terbentuk. Menurut (Retnasari and Hidayah 2019), “TPQ mempunyai 
peran yang strategis dalam usaha peneguhan pendidikan karakter religius". Kegiatan ini berupa pendam-pingan belajar kepada para santri TPA mengenai agama islam, pada khususnya bagaimana siswa bisa membaca Al-Quran dengan baik dan benar serta betakhlak mulia. Siswa diajarkan untuk dapat membaca AlQur'an dengan baik dan benar serta diajarkan mengenai pengetahuan-pengetahuan agama dan cara-cara melaksanakan ibadah kepada Allah. Kegiatan ini bertujuan agar santri TPA agar berakhlak mulia, lebih memahami lagi tentang agamanya, dan mampu membaca Al-Qur'an dengan baik dan benar. Kegiatan ini disasar kepada anak yang masih menempuh pendidikan SD maupun SMP.

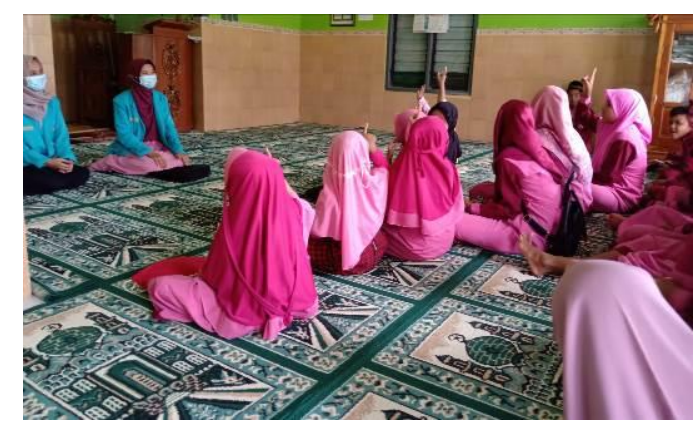

Gambar 5. Kegiatan Pendampingan Belajar TPA

Pendampingan Belajar TPA dilaksana-kan secara rutin setiap satu minggu tiga kali pada hari Senin, Selasa, dan Rabu. Kegiatan ini diikuti kurang lebih 21 siswa secara rutin. Pelaksanaan kegiatan ini berjalan secara lancar tanpa ada suatu kendala yang berarti. Kegiatan diawali dengan pembacaan surat pendek secra bersamaan, dilanjutkan dengan pembacaan Iqro' dan al-Qur'an sesuai dengan kemampuan masing-masing siswa, dan diakhiri dengan penyampaian materi, penyampaian motivasi, serta memberikan ice breaking islami. Siswa merasa senang dengan kegiatan ini. Kemampuan membacaAl-Quran siswa mengalami peningkatan dan pemahaman mereka mengenai islam serta karakter mereka juga mengalami kemajuan.

Kegiatan pendampingan belajar TPA yang dilaksanakan di Dukuh Gempol, Desa Mojodoyong, Kecamatan Kedawung, Kabupaten Sragen menunjukkan adanya peningkatan kelancaran membaca Al-Quran oleh siswa dan peningkatan pemahaman siswa mengenai pegetahuan islam. TPA merupakan program yang mampu meningkatkan pemahaman agama dan budi pekerti siswa. Hal serupa juga 
INTEGRITAS : Jurnal Pengabdian

Vol 5 No 2 Desember 2021

ISSN 2580 - 7978 (cetak) ISSN 2615 - 0794 (online)

disampaikan oleh (Setiawan 2017), bahwa Taman Pendidikan Al-Qur'an (TPA) memiliki peran yang baik dalam membantu santri membaca Al-Qur'an dengan baik dan benar.

Kegiatan pengabdian mulai dari sosialisasi hingga pendampingan belajar dan TPA berjalan dengan lancar tanpa ada suatu kendala yang berarti sesuai dengan tujuan awal yaitu untuk mengembangkan minat belajar anak melalui kegiatan bimbingan belajar, meringankan beban orang tua dalam pendampingan pembelajaran daring, dan merevitalisasi pendidikan yang sudah ada di masa pandemi. Hal ini dapat dilihat dari hasil observasi dan wawancara yang telah dilakukan bahwa siswa memiliki minta dan antusias yang tinggi dalam pelaksanaan program pendam-pingan belajar, bahkan siswa meminta untuk program pendampingan belajar ini terus dilaksanakan saat BDR. Orang tua siswa juga merasa senang dan terbantu dengan adanya program pendampingan belajar karena dapat meringankan beban orangtau dalam mendam-pingi anaknya saat pembelajaran daring atau BDR.

\section{KESIMPULAN}

Pendidikan merupakan hal terpenting yang harus dilaksanakan walaupun dalam keadaan apapun guna mencapai salah atu tujuan nasional bangsa Indonesia yaitu mencerdaskan kehidupan bangsa. Pada Masa pandemi, untuk mencegah penyebaran yang lebih luas lagi maka mengharuskan pembe-lajaran dilaksanakan secara daring atau BDR. Pembelajaran daring atau BDR tidak bisa dilaksanakan secara mandiri oleh siswa jenjang pendidikan dasar. Siswa memerlukan bantuan dalam melaksa-nakan pembelajaran secara daring. Oleh karena itu siswa memerlukan pendampingan dalam pembela-jaran daring agar mampu menyelesaikan tugas belajarnya serta mampu tumbuh dan berkembang sesuai dengan masanya. Hal inilah yang menjadi acuan kami untuk membentuk serta melaksanakan program kerja KKN-Dik di Dukuh Gempol Rt/Rw 18/05, Desa Mojodoyong, Kecamatan Kedawung, Kabupaten Sragen. 


\section{UCAPAN TERIMA KASIH}

Terima kasih kami ucapkan kepada Fakultas Keguruan dan Ilmu Pendidikan Universitas Muhammadiyah Surakarta yang telah mewadahi terselenggaranya KKN-Dikmas tahun 2021, selain itu terima kasih kepada warga Dukuh Gempol telah mensukseskan pengabdian ini, serta semua pihak yang telah membantubaik secara langsung maupun tidak langsung.

\section{DAFTAR PUSTAKA}

Alpian, Y. dkk. (2020). Sosialisasi Peran Orang Tua di Masa Pandemik Covid-19 dalam Pembelajaran Daring bagi Anak Usia Sekolah Dasar Desa Cikalongsari Karawang. Jurnal Buana Pengabdian, 2(2), 31-38.

Arifa, 1. (2020). Tantangan Pelaksanaan Kebijakan Belajar dari Rumah Dalam Masa Darurat COVID-19. Info Singkat, 12(7), 12-18.

Borualogo, I. (2005). Rekonstruksi dan Revitalisasi Pendidikan Indonesia Guna Meningkatkan Kualitas Bangsa. Jurnal Sosial dan Pembangunan, 20(4), 508-24.

Handayani, T dkk. (2020). Pendampingan Belajar di Rumah bagi Siswa Sekolah Dasar Terdampak COVID-19. Jurnal Pengabdian Kepada Masyarakat, 1(1), 107-15.

Indonesia, Rebublik. (2020). Surat Edaran No 4 Tahun 2020 Tentang Pelaksanaan Kebijakan Pendidikan Dalam Masa Darurat Penyebaran Corona Virus Disease(COVID- 19). Jakarta: Menteri Pendidikan dan Kebudayaan Republik Indonesia.

Indonesia, Republik. (2003). Undang-Undang Republik Indonesia Nomor 20 Tahun 2003 Tentang Sistem Pendidikan Nasioanl. Jakarta.

Islami, A. (2021). Peran Orang Tua dalam Pembelajaran Daring Kelas III MI Mi'rojul Ulum Jotangan Kecamatan Mojosari Kabupaten Mojokerto. Skripsi S1

Mawar, D, dan Allif L. (2020). Sosialisasi Peranan Orang Tua dalam Pembelajaran Daring bagi Anak Usia Dini di Masa Pandemi COVID-19. Jurnal UMJ, 1(1), 1-10.

Nurpratiwiningsih, L, Novi Y, dan Prasetyo Y. (2021). Sosialisasi Pendampingan Orang Tua terhadap Proses Belajar Anak Selama Masa Pandemi COVID19. Jurnal Abdi Masyarakat UMUS, 1(2), 31-36.

Prayitno, H dkk. (2018). Panduan Kuliah Kerja Nyata Pendidikan (KKN-Dik) Berbasis Sekolah. III. Surakarta: Muhammadiyah University Press.

Purwanto, Agus dkk. (2020). Studi Eksploratif Dampak Pandemi COVID-19 Terhadap Proses Pembelajaran Online Di Sekolah Dasar. Journal of Education, Psychology and Counseling, 2(1), 1-12. 
Retnasari, L dan Yayuk H. (2019). Penguatan Peran Taman Pendidikan Alquran ( TPQ ) Sebagai Pendidikan Karakter Religius. Jurnal SOLMA, 08(01), 32-38.

Setiawan, W. (2017) Era Digital dan Tantangannya. Seminar Nasional Pendidikan 2017. Universitas Pendidikan Indonesia. Sukabumi, 09 Agustus 2017.

Sudarti dkk. (2021). Pendampingan Belajar Daring di Masa Pandemi COVID-19 untuk Meningkatkan Motivasi dan Hasil Belajar Siswa di Desa Walikukun, Kecamatan Widodaren, Kabupaten Ngawi Provinsi Jawa Timur. Jurnal Pendidikan dan Pengabdian Masyarakat, 4(1), 71-76.

Yulianingsih, W dan Rivo N. (2021). Keterlibatan Orangtua dalam Pendampingan Belajar Anak Selama Masa Pandemi COVID-19. Jurnal Obsesi: Jurnal Pendidikan Anak Usia Dini, 5(2), 1138-50. 